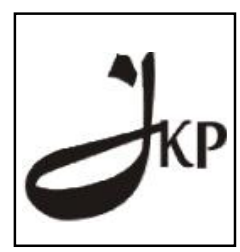

Jurnal Konseling dan Pendidikan

ISSN Cetak: 2337-6740 - ISSN Online: 2337-6880

http://jurnal.konselingindonesia.com

Volume 1 Nomor 2, Juni 2013, HIm 83-94

Info Artikel:

Diterima 04/05/2013

Direvisi 12/06/2013

Dipublikasikan 30/06/2013

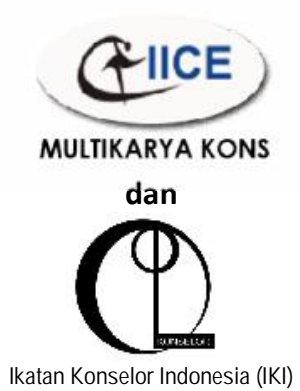

\title{
Kesiapan Guru Bimbingan dan Konseling Menjalani Penilaian Kinerja Guru
}

\author{
Mirza $^{1}$, Prayitno $^{2}$, Daharnis $^{3}$ \\ ${ }^{123}$ Fakultas Ilmu Pendidikan, Universitas Negeri Padang
}

\begin{abstract}
The aim of this research is to reveal the readiness of guidance and counseling teachers toward Teacher's Performance Assesment (TPA) at the quality of their understanding and attitude by using quantitativedescriptive method.The subject of this research is all guidance and counseling teachers at State Senior High Schools and State Vocational High School in Batu Bara District, North Sumatera Province. The number of the research subjects is 33 persons. Semantic differential model scale is the instrument being used in this research to measure the understanding and attitude of research subjects toward TPA.Statistic technique of Mann Whitney $U$ is used to compare the data of two independent samples, and of Kruskal Wallis One Way Anova is used to compare the data of more than two independent samples, and Correlation Product Moment to see the correlation of the data.Based on the results of data analysis, it can be concluded that the readiness scores of research subjects toward TPA are not in good category
\end{abstract}

Keyword: Teacher's Performance Assessment, Guidance and Counseling Teacher, Readiness, Understanding and Attitude

Copyright (C) 2013 IICE - Multikarya Kons (Padang - Indonesia) dan IKI - Ikatan Konselor Indonesia - All Rights Reserved Indonesian Institute for Counseling and Education (IICE) Multikarya Kons

\section{PENDAHULUAN}

Hasil penelitian United Nation Development Programe (UNDP) tentang indeks pengembangan manusia negara berkembang, pada tahun 2007 Indonesia berada pada peringkat ke-111 dari 158 negara yang diteliti. Indonesia memperoleh indeks 0,734 , dan jika Indonesia dibandingkan dengan negara-negara ASEAN yang dilibatkan dalam penelitian itu, Indonesia berada pada peringkat ke-3 dari 4 negara ASEAN, di bawah Thailand dan Filipina.

Mutu pendidikan di Indonesia juga dinyatakan oleh United Nation Educational, Scientific, and Cultural Organization (UNESCO), yaitu bahwa peringkat Indonesia dalam bidang pendidikan pada negara-negara berkembang pada tahun 2008, adalah 69 diantara 127 negara di dunia. Education Development Index (EDI) Indonesia adalah 0,934 di bawah Malaysia $(0,945)$ dan Brunei Darussalam $(0,965)$.

Mutu pendidikan di Indonesia juga tercermin dari daya saing di tingkat internasional, daya saing Indonesia menurut Wordl Economic Forum, (2011-2012), berada di level 46 dari 142 negara. Jauh di bawah peringkat daya saing sesama negara ASEAN seperti Malaysia yang berada di urutan ke-21 dan Singapura pada urutan ke-2.

\footnotetext{
* Telp atau Alamat Email Koresponden :

${ }^{1}$ E-mail address: mirza@konselor.org
} 
Salah satu unsur utama dalam penentuan komposit indeks pengembangan manusia, indeks pengembangan pendidikan dan daya saing SDM seperti yang diuraikan di atas adalah tingkat pengetahuan bangsa atau pendidikan bangsa.Peringkat Indonesia dalam kualitas sumber daya manusia ini adalah gambaran output dari sistem dan proses pendidikan Indonesia.

Lebih khusus lagi, terkait dengan proses dan sistem pendidikan, kualitas proses kegiatan belajar peserta didik cenderung diwarnai oleh nuansa apa yang disebut oleh Prayitno (2011:6) sebagai 5-H (harus, hapal, hampa, hardik, dan hukuman) oleh pendidik dan bermuara kepada peserta didik yang hanya 5-D (datang, duduk, diam, dengar, dan tidak peduli). Dapat diprediksi bagaimana kualitas hasil belajar jika nuansa proses kegiatan belajar tersebut selalu mewarnai dunia pendidikan Indonesia.

Mengenai kualitas hasil belajar peserta didik, angka-angka persentase kelulusan siswa dari tahun ke tahun mengalami peningkatan yang cukup signifikan. Pada tahun 2012, persentase kelulusan siswa dalam Ujian Nasional secara umum mencapai angka 99,50\%. Tingginya angka kelulusan yang dicapai itu menimbulkan berbagai pertanyaan jika dikaitkan dengan berbagai kondisi lapangan.

Kondisi-kondisi di lapangan yang dimaksud di atas, yaitu: (1) praktik nyontek saat ujian menggejala di berbagai daerah, tidak heran memang, sebab kualitas kegiatan belajar peserta didik pada umumya masih bernuansa 5-H oleh pendidik dan bermuara 5-Doleh peserta didik, (2) menjamurnya lembaga-lembaga bimbingan belajar yang salah satu tujuannya adalah mempersiapkan peserta didik untuk lulus ujian nasional, tentu yang menjadi pertanyaan adalah apakah peran pendidik di sekolah belum maksimal?, (3) sarana dan prasarana pendidikan yang belum memadai di berbagai daerah, sekali lagi pertanyaan yang muncul adalah apakah proses pembelajaran bisa terjamin mutu dan kualitasnya?.

Berbagai permasalahan yang dipaparkan di atas menjadi tanggungjawab besar bagi stakeholder dunia pendidikan, tidak hanya selalu menyalahkan pemerintah selaku penyelenggara negara, sebab banyak faktor-faktor lain yang luput dari perhatian. Secara garis besar, menurut penulis ada tiga faktor yang mempengaruhi mutu pendidikan di Indonesia, yaitu : (1) manajemen pendidikan, (2) kualitas pendidik, dan (3) peran serta masyarakat. Faktor yang kedua di atas menjadi fokus utama pemerintah saat ini (tanpa mengabaikan faktor yang lain) untuk diupayakannya pendidik menjadi profesional.

Dalam UU No. 20 Tahun 2003 Pasal 39 Ayat 2 tentang Sistem Pendidikan Nasional ditegaskan bahwa:

Pendidik merupakan tenaga profesional yang bertugas merencanakan dan melaksa-nakan proses

pembelajaran, menilai hasil pembelajaran, melakukan pembimbingan dan pelatihan, serta melakukan penelitian dan pengabdian kepada masyarakat, terutama bagi pendidik pada perguruan tinggi.

Kualifikasi pendidik adalah sebagaimana yang ditegaskan dalam Undang-Undang Nomor 20 Tahun 2003 Pasal 1 Ayat 6 tentang Sistem Pendidikan Nasional, yaitu:

Pendidik adalah tenaga kependidikan yang berkualitas sebagai guru, dosen, konselor, pamong

belajar, widyaiswara, tutor, instruktur, fasilitator, dan sebutan lain yang sesuai dengan kekhususannya, serta berpartisipasi dalam menyelenggarakan pendidikan.

Lebih khusus lagi, terkait dengan tenaga kependidikan pada jenjang pendidikan dasar dan menengah, yaitu guru, masih banyak permasalahan yang selalu membayangi, salah satunya adalah kualitas guru di Indonesia, khususnya dapat dilihat dari kelayakan guru mengajar. Menurut Badan Penelitan dan Pengembangan Departemen Pendidikan Nasional, pada tahun 2010 guru-guru yang layak mengajar untuk tingkat sekolah menengah, yaitu: (1) guru SMP negeri dan swasta 87.30\%, (2) guru SMA negeri dan swasta 80.26\%, dan (3) guru SMK negeri dan swasta $81.16 \%$. Kondisi ini menjadi tantangan besar bagi penyelenggara pendidikan untuk terus meningkatkan kualitas guru agar mencapai taraf yang benar-benar profesional.

Gambaran umum tentang kualitas guru BK di Indonesia terungkap dalam penelitian yang dilakukan oleh Abul Murad (2005), studi yang dilakukan pada lingkungan pakar konseling perguruan tinggi negeri dan guru BK SMA Negeri. Hasil penelitian ini menunjukkan bahwa : (1) tingkat kinerja aktual kompetensi guru BK secara menyeluruh berada pada tingkat sedang $(67,61 \%)$, (2) tingkat kinerja aktual kompetensi guru BK dari latar belakang konseling berada di tingkat tinggi (70,13\%), sedangkan guru BK dengan latar belakang non-konseling berada di menengah $(63,67 \%)$. 
Dalam upaya profesionalisasi guru yang paling baru saat ini, pemerintah akan mulai memberlakukan program Penilaian Kinerja Guru (selanjutnya disingkat PKG), yang dilaksanakan sesuai dengan aturan yang berlaku, yang menjamin terjadinya proses pembelajaran yang berkualitas di semua jenjang pendidikan. Aturan ini dituangkan dalam Peraturan Menteri Negara Pendayagunaan Aparatur Negara dan Reformasi Birokrasi Nomor 16 Tahun 2009 tentang Jabatan Fungsional Guru dan Angka Kreditnya, dijelaskan bahwa PKG adalah penilaian untuk tiap butir kegiatan tugas utama dalam rangka pembinaan karir, kepangkatan, dan jabatan.

Secara etimologi, kinerja berasal dari kata prestasi kerja (performance). Sebagaimana dikemukakan oleh L.A.N (Sedarmayanti, 2009:50) bahwa "performance diterjemahkan menjadi kinerja, juga berarti prestasi kerja, pelaksanaan kerja, pencapaian kerja atau hasil kerja/unjuk kerja/penampilan kerja”. Selanjutnya, dalam kamus bahasa Inggris (Peter Salim, 1987:1386) "kinerja atau performance dimaknai sebagai perbuatan, pelaksanaan, pertunjukan, dan pelaksanaan kontrak sesuai dengan syarat-syarat yang ditentukan bersama". Selain itu, kinerja dapat pula dimaknai sebagai "achievement" yang berarti hasil, atau prestasi, atau pencapaian.

Dalam rangka melacak kemajuan kinerja, mengidentifikasi kendala, dan memberi informasi dalam suatu organisasi, diperlukan adanya komunikasi kinerja yang berlangsung terus menerus, sehingga dapat mencegah dan menyelesaikan maslah yang terjadi. Karena alasan sebenarnya mengelola kinerja adalah untuk meningkatkan produktivitas, serta menrancang bangun kesuksesan bagi setiap pekerja.

Terkait dengan pengelola kinerja, Prayitno (2009:476) menjelaskan bahwa pengelolaan kegiatan pelayanan pendidikan pada satuan kerja (misalnya di sekolah/madrasah) diselenggarakan dengan pola Pengelolaan Barbasis Kinerja Profesional dengan pengawasan/pembinaan yang efektif baik dari pihak interen maupun eksteren sekolah/madrasah.

Para pendidik profesional sangat berkepe-ntingan dengan pola yang dimaksudkan itu apabila mereka hendak menepati tanggung jawab profesinya. Selanjutnya dijelaskan pula bahwa pengelolaan dalam bidang kegiatan atau bidang kerja tertentu pada dasarnya terfokus pada empat pilar kegiatan, yaitu perencanaan (planning), pengorganisasian (organizing), pelaksanaan (actuating), dan pengontrolan (controlling), ditambah pilar kelima, yaitu tindak lanjut

Senada dengan hal tersebut, Bernardin \& Russell (Ruky, 2001:8) menyatakan bahwa: "Perlu diadakan penilaian kinerja, untuk mengelola dan memperbaiki kinerja karyawan untuk membuat keputusan staf yang tepat waktu dan akurat dan untuk mempertinggi kualitas produksi dan jasa perusahaan secara keseluruhan".

Sementara menurut Gomes (2003:135) penilaian kinerja mempunyai tujuan untuk me-reward kinerja sebelumnya (to reward past performance) dan untuk memotivasi demi perbaikan kinerja pada masa yang akan datang (to motivate future performance improvement), serta informasi-informasi yang diperoleh dari penilaian kinerja ini dapat digunakan untuk kepentingan pemberian gaji, kenaikan gaji, promosi, pelatihan dan penempatan tugas-tugas tertentu.

Suksesnya pelaksanaan PKG perlu ditunjang dengan kesiapan yang matang dan memadai. Terkait dengan kesiapan ini yang terpenting adalah guru BK atau konselor perlu memiliki pengetahuan, pemahaman, persepsi, dan sikap yang memadai mengenai tujuan penilaian, apa yang dinilai, bagaimana proses pengukuran, siapa yang menilai, seperti apa hasil yang mungkin diperoleh, dan bagaimana implikasi jika berhasil memperoleh nilai yang memenuhi standar atau jika tidak memenuhi standar.

Kesiapan berasal dari kata "siap" mendapat awalan ke- dan akhiran an. Dalam kamus besar Bahasa Indonesia (2003) "kesiapan adalah suatu keadaan bersiap-siap untuk mempersiapkan sesuatu". Dalam hal ini kesiapan berhubungan erat dengan proses, cara, perbuatan, menyiapkanatau menyediakan sesuatu. Selanjutnya Slameto (1995:113) menyatakan "Kesiapan adalah keseluruhan kondisi seseorang/individu yang membuatnya siap untuk memberikan respons/jawaban di dalam cara tertentu terhadap suatu situasi”.

Dalam kamus Konseling dan Psikoterapi (Andi Mappiare A.T, 2006:272) dijelaskan, readiness (kesiapan) adalah kesiapan fisik, fisiologis, dan psikologis subjek untuk bereaksi atau merespon, selanjutnya dikelaskan pula "kesiapan" adalah kata lain dari 'kesiapan tugas' (task readliness), yaitu menunjuk pada kesiapan orang (misalnya, pekerja, murid, klien untuk melaksanakan tugas). Selanjutnya Hasan (2002:1009) menjelaskan kesiapan adalah kesediaan untuk melakukan sesuatu.

Berdasarkan informasi yang didapatkan dari guru BK di beberapa SMA dan SMK Negeri di Kabupaten Batu Bara Provinsi Sumatera Utara, sosialisasi ataupun akses informasi tentang PKG masih sangat minim didapatkan. Hal ini diasumsikan oleh penulis akan berimbas kepada kesiapan mereka menghadapi PKG. Ini dapat dilihat dari pernyataan guru BK tentang pengetahuan, persepsi, pemahaman dan sikap mereka terhadap PKG. 
Selain itu data yang ditemukan dari Dinas Pendidikan Kabupaten Batu Bara Provinsi Sumatera Utara menunjukkan bahwa kualifikasi akademik yang menjadi prasyarat dalam PKG belum terpenuhi, masih banyak guru BK yang tidak berlatar belakang kualifikasi pendidikan non-BK dan belum ada satupun konselor yang diangkat dan bertugas pada satuan-satuan pendidikan yang ada, hal ini diasumsikan akan berimbas terhadap kesiapan mereka menghadapi pemberlakuan PKG.

Dalam tataran nasional PKG ini menjadi topik yang paling sering dibicarakan, dalam jejaring sosial group Asosiasi Bimbingan dan Konseling Indonesia (ABKIN) di Facebook, ditemukan 45 topik diskusi dalam kurun waktu Desember 2011 sampai dengan Juni 2012 yang membicarakan tentang PKG. Isi dan arah diskusi mengisyaratkan kerisauan para guru BK dalam menghadapi PKG, dari beberapa topik diskusi yang diamati menurut penulis kerisauan ini antara lain disebabkan oleh kurang memadainya pengetahuan, pemahaman, persepsi, dan sikap mengenai tujuan penilaian, apa yang dinilai, bagaimana proses pengukuran, siapa yang menilai, seperti apa hasil yang mungkin diperoleh, dan bagaimana implikasi jika berhasil memperoleh nilai yang memenuhi standar atau jika tidak memenuhi standar.

Berdasarkan uraian fenomena dan gejala di atas serta pandangan para ahli, maka dalam hal ini, peneliti melakukan penelitian tentang kesiapan guru BK menjalani PKG yang meliputi kualitas pemahaman dan sikap mereka terhadap PKG, dan perbedaannya berdasarkan variabel jenis kelamin, unit tugas, masa kerja, kualifikasi pendidikan serta hubungan antara kualitas pemahaman dan sikap terhadap PKG.

\section{METODOLOGI}

Tujuan penelitian ini adalah untuk mengungkapkan kesiapan guru bimbingan dan konseling (disingkat guru BK) dalam menjalani Penilaian Kinerja Guru dengan menggunakan metode deskriptif-kuantitatif.Subjek penelitian adalah seluruh guru BK di SMA dan SMK Negeri se-Kabupaten Batu Bara Provinsi Sumatera Utara yang berjumlah 33 orang.

Instrumen yang digunakan adalah skala model Semantic Differential. Untuk melihat kualitas kesiapan guru BK menjalani PKG digunakan norma kategorisasi, yaitu kategori sangat tinggi, tinggi (kriteria kualitas baik), sedang, rendah dan sangat rendah (kriteria kualitas kurang baik). Data tentang perbedaan dianalis dengan menggunakan teknik statistik uji beda Mann Whitney $U$ (komparatif dua sampel independen), dan Kruskal Wallis One Way Anova (komparatif lebih dua sampel independen), sedangkan untuk melihat hubungan digunakan rumus Correlation Product Moment.

\section{HASIL DAN PEMBAHASAN}

Kondisi kualitas pemahaman guru BK menjalani PKG tercantum pada Tabel 1 berikut.

Tabel 1.

Rekapitulasi Kualitas Pemahaman Guru BK terhadap PKG

\begin{tabular}{|c|c|c|c|c|c|c|c|c|c|c|c|c|}
\hline \multirow{3}{*}{ NO } & \multirow{3}{*}{ VARIABEL /SUB-VARIABEL } & \multicolumn{10}{|c|}{ KUALITAS PEMAHAMAN } & \multirow{3}{*}{ TOTAL (\%) } \\
\hline & & \multirow{2}{*}{$\begin{array}{l}\text { ST } \\
f\end{array}$} & \multirow{2}{*}{$\begin{array}{c}(<144) \\
\% \\
\end{array}$} & \multicolumn{2}{|c|}{ T $\quad(<120$ s.d $\leq 144)$} & \multicolumn{2}{|c|}{ s $\quad(<96$ s.d $\leq 120)$} & \multicolumn{2}{|c|}{ R $\quad(<72$ s.d $\leq 96)$} & \multicolumn{2}{|c|}{ SR $\quad(\leq 72)$} & \\
\hline & & & & $f$ & $\%$ & $f$ & $\%$ & $f$ & $\%$ & $f$ & $\%$ & \\
\hline 1 & UMUM & 1 & 3,03 & 7 & 21,21 & 9 & 27,27 & 8 & 24,24 & 8 & 24,24 & 100 \\
\hline \multirow[t]{3}{*}{2} & \multicolumn{12}{|l|}{ JENIS KELAMIN } \\
\hline & a. Laki-Laki & 1 & 3,03 & 3 & 9,09 & 3 & 9,09 & 5 & 15,15 & 4 & 12,12 & 48,48 \\
\hline & b. Perempuan & - & - & 4 & 12,12 & 6 & 18,18 & 3 & 9,09 & 4 & 12,12 & 51,52 \\
\hline \multirow[t]{4}{*}{3} & \multicolumn{12}{|l|}{ KUALIFIKASI PENDIDIKAN } \\
\hline & a. D-III BK & - & - & 1 & 3,03 & - & - & 3 & 9,09 & - & - & 12,12 \\
\hline & b. S-I BK & 1 & 3,03 & 5 & 15,15 & 6 & 18,18 & 2 & 6,06 & 2 & 6,06 & 48,48 \\
\hline & c. S-I Non-BK & - & - & 1 & 3,03 & 3 & 9,09 & 3 & 9,09 & 6 & 18,18 & 39,39 \\
\hline \multirow[t]{4}{*}{4} & \multicolumn{12}{|l|}{ MASA KERJA } \\
\hline & a.0-11 Tahun & 1 & 3,03 & 5 & 15,15 & 4 & 12,12 & 3 & 9,09 & 6 & 18,18 & 57,58 \\
\hline & b. 12 - 23 Tahun & - & - & 1 & 3,03 & 4 & 12,12 & 2 & 6,06 & 2 & 6,06 & 27,27 \\
\hline & c. $\geq 24$ Tahun & - & - & 1 & 3,03 & 2 & 6,06 & 2 & 6,06 & - & - & 15,15 \\
\hline \multirow[t]{3}{*}{5} & UNIT TUGAS & & & & & & & & & & & \\
\hline & a. SMA & 1 & 3,03 & 6 & 18,18 & 7 & 21,21 & 5 & 15,15 & 5 & 15,15 & 72,73 \\
\hline & b. SMK & - & - & 1 & 3,03 & 2 & 6,06 & 3 & 9,09 & 3 & 9,09 & 27,27 \\
\hline
\end{tabular}


Berdasarkan Tabel 1 di atas, dapat dijelaskan kondisi kesiapan guru BK menjalani PKG berdasarkan kualitas pemahaman terhadap PKG, secara umum bervariasi mulai dari krieria kualitas baik (kategori sangat tinggi dan tinggi) hingga kurang baik (kategori sedang, rendah dan sangat rendah). Dari 33 orang guru BK hanya 8 orang $(24,24 \%)$ yang berada pada kriteria kualitas baik. Sedangkan 25 orang $(75,76 \%)$ berada pada kriteria kualitas kurang baik.

Guru BK perempuan memiliki kriteria kualitas baik (12,12\%) sama dengan guru BK laki-laki $(12,12 \%)$, posisi kriteria kualitas baik berdasarkan kualifikasi pendidikan pertama diduduki oleh guru BK dengan kualifikasi S-I BK $(18,18 \%)$ dan diikuti oleh kualifikasi D-III BK dan S-I Non-BK dengan posisi yang sama $(3,03 \%)$, berdasarkan masa kerja kriteria kualitas baik pertama diduduki oleh guru BK dengan masa kerja $0-11$ tahun (18.18\%) kemudian diikuti oleh guru BK dengan masa kerja 12 - 23 tahun $(3,03 \%)$, selanjutnya berdasarkan unit tugas pada kriteria kualitas baik guru BK SMA berada pada posisi pertama $(21,21 \%)$ kemudian diikuti oleh guru BK SMK $(3,03 \%)$.

Kondisi sikap guru BK terhadap PKG hasilnya terlihat pada Tabel 2 berikut.

Tabel 2.

Rekapitulasi Kondisi Sikap Guru BK terhadap PKG

\begin{tabular}{|c|c|c|c|c|c|c|c|c|c|c|c|c|}
\hline \multirow{3}{*}{ NO } & \multirow{3}{*}{ VARIABEL /SUB-VARIABEL } & \multicolumn{10}{|c|}{ KATEGORI SIKAP } & \multirow{3}{*}{ TOTAL (\%) } \\
\hline & & \multirow{2}{*}{$\begin{array}{l}\text { ST } \\
f\end{array}$} & \multirow{2}{*}{$\begin{array}{c}<77) \\
\%\end{array}$} & \multicolumn{2}{|c|}{$\mathrm{T} \quad(\leq 77 \mathrm{~s} . \mathrm{d}<64)$} & \multicolumn{2}{|c|}{$s \quad(\leq 64$ s.d $<50)$} & \multicolumn{2}{|c|}{$R \quad(\leq 50$ s.d $<37)$} & \multicolumn{2}{|c|}{$S R(\leq 37)$} & \\
\hline & & & & $f$ & $\%$ & $f$ & $\%$ & $f$ & $\%$ & $f$ & $\%$ & \\
\hline 1 & UMUM & - & - & 2 & 6,06 & 6 & 18,18 & 6 & 18,18 & 19 & 57,58 & 100 \\
\hline \multirow[t]{3}{*}{2} & \multicolumn{12}{|l|}{ JENIS KELAMIN } \\
\hline & a. Laki-Laki & - & - & 2 & 6,06 & 6 & 18,18 & 5 & 15,15 & 3 & 9,09 & 48,48 \\
\hline & b. Perempuan & - & - & - & - & - & - & 1 & 3,03 & 16 & 48,48 & 51,52 \\
\hline \multirow{2}{*}{3} & b. S-I BK & - & - & 4 & 12,12 & 5 & 15,15 & 6 & 18,18 & 1 & 3,03 & 48,48 \\
\hline & c. S-I Non-BK & - & - & 1 & 3,03 & 7 & 21,21 & 5 & 15,15 & - & - & 39,39 \\
\hline \multirow[t]{3}{*}{4} & \multicolumn{12}{|l|}{ MASA KERJA } \\
\hline & a.0-11 Tahun & - & - & 5 & 15,15 & 7 & 21,21 & 6 & 18,18 & 1 & 3,03 & 57,58 \\
\hline & b. $12-23$ Tahun & - & - & 1 & 3,03 & 5 & 15,15 & 3 & 9,09 & 3 & 9,09 & 36,36 \\
\hline 5 & b. SMK & - & - & - & - & 6 & 18,18 & 3 & 9,09 & - & - & 27,27 \\
\hline
\end{tabular}

Berdasarkan Tabel 2 di atas, dapat dijelaskan kondisi kesiapan guru BK menjalani PKG berdasarkan skor sikap terhadap PKG secara umum bervariasi, mulai dari kriteria kualitas baik (kategori sangat tinggi dan tinggi) hingga kriteria kualitas kurang baik (kategori sedang, rendah dan sangat rendah). Dari 33 orang guru BK hanya 2 orang $(6,06 \%)$ yang berada pada kriteria kualitas baik. Sedangkan 31 orang $(93,94 \%)$ berada pada kriteria kualitas kurang baik.

Guru BK laki-laki memiliki kriteria kualitas baik $(6,06 \%)$ sedangkan guru BK perempuan seluruhnya berada pada kriteria kualitas kurang baik $(51,52 \%)$, posisi kriteria kualitas baik berdasarkan kualifikasi pendidikan pertama diduduki oleh guru BK dengan kualifikasi S-I BK $(12,12 \%)$ dan diikuti oleh kualifikasi D-III BK dan S-I Non-BK dengan posisi yang sama $(3,03 \%)$, berdasarkan masa kerja kriteria kualitas baik pertama diduduki oleh guru BK dengan masa kerja 0 - 11 tahun $(15.15 \%)$ kemudian diikuti oleh guru BK dengan masa kerja $12-23$ tahun $(3,03 \%)$, selanjutnya berdasarkan unit tugas pada kriteria kualitas baik guru BK SMA berada di posisi pertama (18,18\%) sedangkan guru BK SMK seluruhnya berada pada kriteria kualitas kurang baik $(27,27 \%)$.

Perbedaan kualitas pemahaman guru BK terhadap PKG berdasarkan variabel jenis kelamin, unit tugas dan kualifikasi pendidikan hasilnya dapat dilihat pada tabel berikut. 
Tabel 3.

Perbedaan Kualitas Pemahaman Guru BK terhadap PKG berdasarkan Jenis Kelamin, Unit Tugas, Kualifikasi Pendidikan

\begin{tabular}{|c|c|c|c|c|c|c|}
\hline \multirow{2}{*}{ No. } & Variabel/ & \multirow{2}{*}{$\mathbf{N}$} & \multirow{2}{*}{$\begin{array}{l}\text { Rangking } \\
\text { Rata-Rata }\end{array}$} & \multicolumn{3}{|c|}{ Tes Statistik } \\
\hline & Su-Variabel & & & $\begin{array}{c}\text { Nilai Mann } \\
\text { Whitney } U\end{array}$ & Nilai Uji Z & Signifikansi \\
\hline \multirow{3}{*}{1} & \multicolumn{3}{|l|}{ Jenis Kelamin } & \multirow{3}{*}{125} & \multirow{3}{*}{$-0,397$} & \multirow{3}{*}{0,691} \\
\hline & a. Laki-Laki & 16 & 16,31 & & & \\
\hline & b. Perempuan & 17 & 17,65 & & & \\
\hline \multirow{3}{*}{2} & Unit Tugas & & & \multirow{3}{*}{83,5} & \multirow{3}{*}{$-0,992$} & \multirow{3}{*}{0,321} \\
\hline & a. SMA & 24 & 18,02 & & & \\
\hline & b. SMK & 9 & 14,28 & & & \\
\hline \multirow{3}{*}{3} & Kualifikasi Pendidika & & & \multirow{3}{*}{50} & \multirow{3}{*}{$-2,37$} & \multirow{3}{*}{0,018} \\
\hline & a. $\mathrm{S} 1-\mathrm{BK}$ & 16 & 18,38 & & & \\
\hline & b. S1 Non-BK & 13 & 10,85 & & & \\
\hline
\end{tabular}

Dari Tabel 3 di atas dapat dijelaskan berdasarkan jenis kelamin rangking nilai rata-rata guru BK perempuan lebih tinggi dibandingkan dengan guru BK laki-laki $(17,65>16,31)$, selanjutnya nilai statistik uji $\mathrm{Z}$ yang kecil, yaitu -0,397 dan nilai sig.2-tailed adalah 0,691 >0,05, karena itu hasil uji tidak signifikan secara statistik. Berdasarkan unit tugas rangking nilai rata-rata guru BK SMA lebih tinggi dibandingkan dengan guru BK SMK $(18,02>14,28)$, selanjutnya nilai statistik uji Z yang kecil yaitu -0,992 dan nilai sig.2-tailed adalah 0,321 >0,05, karena itu hasil uji tidak signifikan secara statistik.

Selanjutnya, berdasarkan kualifikasi pendidikan rangking nilai rata-rata guru BK dengan kualifikasi S-1 BK lebih tinggi dibandingkan dengan S1-Non-BK $(18,38>10,85)$, selanjutnya nilai statistik uji Z yang kecil yaitu 2,370 dan nilai sig.2-tailed adalah 0,018<0,05, karena itu hasil uji signifikan secara statistik

Perbedaan kualitas pemahaman guru BK terhadap PKG berdasarkan variabel masa kerja, hasilnya dapat dilihat pada tabel berikut.

Tabel 4.

Perbedaan Kualitas Pemahaman Guru BK terhadap PKG berdasarkan Masa Kerja

\begin{tabular}{|c|c|c|c|c|c|}
\hline \multirow{2}{*}{ No. } & \multirow{2}{*}{$\frac{\text { Variabel/ }}{\text { Su-Variabel }}$} & \multirow{2}{*}{$\mathbf{N}$} & \multirow{2}{*}{$\begin{array}{l}\text { Rangking } \\
\text { Rata-Rata }\end{array}$} & \multicolumn{2}{|c|}{ Tes Statistik } \\
\hline & & & & $\begin{array}{c}\text { Nilai Chi- } \\
\text { square }\end{array}$ & $\begin{array}{c}\text { Signifikan } \\
\text { si }\end{array}$ \\
\hline \multirow{4}{*}{1} & Masa Kerja & & & \multirow{4}{*}{0,346} & \multirow{4}{*}{0,841} \\
\hline & a. $0-11$ thn & 19 & 17,34 & & \\
\hline & b. $12-23$ thn & 9 & 15,5 & & \\
\hline & c. $\quad \geq 24$ thn & 5 & 18,4 & & \\
\hline
\end{tabular}

Berdasarkan tabel di atas, dapat dijelaskan bahwa rangking nilai rata-rata guru BK dengan masa kerja $\geq 24$ tahun lebih tinggi dibandingkan dengan guru BK dengan masa kerja 0-11 tahun dan 12-23 tahun (18,40>17,34> 15,50) selanjutnya nilai $P$-value $=0,841>\alpha=0,1$, karena itu hasil uji tidak signifikan secara statistik. 
Perbedaan sikap guru BK terhadap PKG berdasarkan variabel jenis kelamin dan unit tugas hasilnya dapat dilihat pada tabel berikut.

Tabel 5.

Perbedaan Sikap Guru BK terhadap PKG berdasarkan Jenis Kelamin, Unit Tugas, Kualifikasi Pendidikan

\begin{tabular}{|c|c|c|c|c|c|c|}
\hline \multirow{2}{*}{ No. } & \multirow{2}{*}{$\frac{\text { Variabel/ }}{\text { Su-Variabel }}$} & \multirow{2}{*}{$\mathbf{N}$} & \multirow{2}{*}{$\begin{array}{l}\text { Rangking } \\
\text { Rata-Rata }\end{array}$} & \multicolumn{3}{|c|}{ Tes Statis tik } \\
\hline & & & & $\begin{array}{l}\text { Nilai Mann } \\
\text { Whitney } U\end{array}$ & Nilai Uji Z & Signifikansi \\
\hline \multirow{3}{*}{1} & \multicolumn{3}{|l|}{ Jenis Kelamin } & \multirow{3}{*}{125} & \multirow{3}{*}{$-0,397$} & \multirow{3}{*}{0,691} \\
\hline & a. Laki-Laki & 16 & 16,31 & & & \\
\hline & b. Perempuan & 17 & 17,65 & & & \\
\hline \multirow{3}{*}{2} & Unit Tugas & & & \multirow{3}{*}{94,5} & \multirow{3}{*}{$-0,547$} & \multirow{3}{*}{0,585} \\
\hline & a. SMA & 24 & 17,56 & & & \\
\hline & b. SMK & 9 & 15,5 & & & \\
\hline \multirow{3}{*}{3} & Kualifikasi Pendidi & & & \multirow{3}{*}{91} & \multirow{3}{*}{$-0,571$} & \multirow{3}{*}{0,568} \\
\hline & $\begin{array}{ll}\text { a. } & \text { S1-BK }\end{array}$ & 16 & 15,81 & & & \\
\hline & b. S1-Non-BK & 13 & 14 & & & \\
\hline
\end{tabular}

Dari Tabel 5 di atas, dapat dijelaskan berdasarkan jenis kelamin rangking nilai rata-rata guru BK perempuan lebih tinggi dibandingkan dengan guru BK laki-laki $(17,65>16,31)$, selanjutnya nilai statistik uji $\mathrm{Z}$ yang kecil yaitu -0,397 dan nilai sig.2-tailed adalah 0,691 >0,05, karena itu hasil uji tidak signifikan secara statistik. Berdasarkan unit tugas rangking nilai rata-rata guru BK SMA lebih tinggi dibandingkan dengan guru BK SMK $(17,56>15,50)$, selanjutnya nilai statistik uji Z yang kecil yaitu -,547 dan nilai sig.2-tailed adalah 0,585 >0,05, karena itu hasil uji tidak signifikan secara statistik.Berdasarkan kualifikasi pendidikan rangking nilai rata-rata guru BK dengan kualifikasi S1-BK lebih tinggi dibandingkan dengan S1-Non-BK $(15,81>14,00)$, selanjutnya nilai statistik uji $\mathrm{Z}$ yang kecil yaitu -,571 dan nilai sig.2-tailed adalah 0,568 >0,05, karena itu, hasil uji tidak signifikan secara statistik.

Perbedaan sikap guru BK terhadap PKG berdasarkan variabel masa kerja hasilnya dapat dilihat pada tabel berikut.

Tabel 6.

Perbedaan Sikap Guru BK terhadap PKG berdasarkan Masa Kerja

\begin{tabular}{|c|c|c|c|c|c|}
\hline \multirow{2}{*}{ No. } & Variabel/ & \multirow{2}{*}{$\mathbf{N}$} & \multirow{2}{*}{$\begin{array}{l}\text { Rangking } \\
\text { Rata-Rata }\end{array}$} & \multicolumn{2}{|c|}{ Tes Statistik } \\
\hline & Su-Variabel & & & $\begin{array}{c}\text { Nilai Chi- } \\
\text { square }\end{array}$ & Signifikansi \\
\hline \multirow{4}{*}{1} & Masa Kerja & & & \multirow{4}{*}{1,592} & \multirow{4}{*}{0,451} \\
\hline & a. $0-11$ thn & 19 & 17,76 & & \\
\hline & b. $12-23$ thn & 9 & 18,17 & & \\
\hline & c. $\quad \geq 24$ thn & 5 & 12 & & \\
\hline
\end{tabular}

Berdasarkan tabel di atas, dapat dijelaskan bahwa rangking nilai rata-rata guru BK dengan masa kerja 12-23 tahun lebih tinggi dibandingkan dengan guru BK dengan masa kerja 0-11 tahun dan 224 tahun(18,17>17,76> 12,00) selanjutnya nilai $P$-value $=, 451>\alpha=0,1$, karena itu hasil uji tidak signifikan secara statistik. 

berikut.

Hubungan antara kualitas pemahaman dan sikap guru BK terhadap PKG hasilnya dapat dilihat pada tabel

Tabel 7.

Hubungan antara Kualitas Pemahaman dan Sikap Guru BK terhadap PKG.

\begin{tabular}{l|c|c|c|}
\multicolumn{1}{c|}{ Variabel } & $\begin{array}{c}\text { Nilai Koefisien } \\
\text { Korelasi }\left(\mathbf{r}_{\mathrm{xy}}\right)\end{array}$ & $\mathbf{r}$ tabel & Keterangan \\
\cline { 3 - 4 } & & $\mathbf{N = 3 3 , \alpha = 0 , 0 5 )}$ & \\
\hline $\mathrm{X}=$ Pemahaman & 0,407 & 0,334 & signifikan \\
\hline $\mathrm{Y}=$ Sikap & & & \\
\hline
\end{tabular}

Dari tabel di atas dapat dijelaskan bahwa dengan taraf kepercayaan 95\% dan $\mathrm{N}=33$, maka harga $\mathrm{r}$ tabel $=$ 0,334 . Ternyata harga $r$ hitung lebih besar dari harga $r$ tabel $(0,407>0,334)$, dengan demikian dapat dikatakan bahwa terdapat hubungan yang signfikan antara variabel $\mathrm{X}$ dan variabel $\mathrm{Y}$

\section{PEMBAHASAN}

Temuan penelitian pertama, mengung-kapkan bahwa secara umum kualitas pema-haman guru BK terhadap PKG yang berada pada kriteria kualitas baik sebesar 24,24\% sedangkan yang berada pada kriteria kualitas kurang baik merupakan sebagian besar dari mereka (75,76\%). Kemudian berdasarkan variabel jenis kelamin, masa kerja, dan unit tugas guru BK tidak terdapat perbedaan kualitas pemahaman dengan angka rata-ratanya cenderung pada kategori rendah. Sedangkan berdasarkan kualifikasi pendidikan S1-BK dan S1 Non-BK terdapat perbedan yang signifikan, dengan angka rata-ratanya guru BK dengan kualifikasi pendidikan S1-BK lebih tinggi dibandingkan dengan guru S1-Non BK.

Perbedaan kualitas pemahaman guru BK berdasarkan kualifikasi pendidikan seperti yang terungkap dalam penelitian ini menggambarkan bahwa guru BK dengan kualifikasi pendidikan S1-BK memiliki kualitas pemahaman yang lebih baik dibandingkan dengan guru BK dengan kualifikasi S1-Non-BK. Hal ini terkait dengan kenyataan bahwa guru BK dengan kualifikasi pendidikan S1-BK pada masa pendidikan di perguruan tinggi telah dipersiapkan (dididik dan dilatih) untuk memiliki seperangkat pemahaman dan kompetensi yang sesuai dengan tugas dan fungsinya sebagai pengampu pelayanan BK pada satuan pendidikan, sebaliknya, guru BK dengan kualifikasi pendidikan S1-Non-BK pada masa pendidikannya tidak secara spesifik dididik dan dilatih untuk memiliki seperangkat pemahaman dan kompetensi sebagai pengampu pelayanan BK. Kondisi ini membawa konsekwensi guru BK dengan kualifikasi S1-BK akan lebih memahami dan menguasai seperangkat materi penilaian dalam PKG.

Selain itu, rendahnya kualitas pemahaman guru BK terhadap PKG yang terungkap dalam penelitian ini juga dipengaruhi oleh berbagai kondisi, antara lain banyaknya guru BK dengan kualifikasi pendidikan Non-BK dan minimnya sosialisasi yang diterima oleh guru BK pada umumnya. Kondisi kualitas pemahaman yang rendah ini jika dibiarkan dapat berimbas terhadap proses maupun hasil pelaksanaan PKG nantinya.

Temuan penelitian kedua, yaitu kesiapan guru BK menjalani PKG pada aspek sikap, menunjukkan bahwa secara umum sikap Guru BK terhadap PKG berada pada kriteria kualitas kurang baik $(93,94)$, dan hanya sebagian kecil yang berada pada kriteria kualitas baik (6,06\%). Selanjutnya berdasarkan variabel jenis kelamin, kualifikasi pendidikan, masa kerja, dan unit tugas guru BK tidak terdapat perbedaan sikap dengan angka rata-ratanya cenderung pada kategori rendah.

Kondisi tersebut di atas tentu saja akan sangat berpengaruh terhadap fungsi dan tujuan dari penilaian kinerja sebagai upaya profesionalisasi guru, dalam hal ini khususnya guru BK. Dalam Pedoman PKG (2010) dijelaskan bahwa pelaksanaan PKG dimaksudkan bukan untuk menyulitkan guru, tetapi sebaliknya PKG dilaksanakan untuk mewujudkan guru dan guru BK yang profesional, karena harkat dan martabat suatu profesi ditentukan oleh kualitas layanan profesi yang bermutu.

Diharapkan dengan sikap yang baik, guru BK akan mampu mengikuti keseluruhan proses penilaian dengan sukses dan mendapatkan hasil yang valid dan reliabel atas kualitas kompetensi yang dimilikinya, sehingga 
menjadi bahan evaluasi atas kinerjanya selama ini. Sebaliknya, dengan kualitas sikap yang rendah, dan dengan pemahaman yang rendah pula, kondisi ini akan akan memberikan kontribusi secara langsung pada proses dan hasil PKG yang dicapai, dan berdampak kurang baikbagi pengembangan karir guru BK yang diharapkan akan menjadi tenaga profesional.

Temuan penelitian ketiga mengungkapkan bahwa terdapat hubungan yang signifikan antara kualitas pemahaman dan sikap guru BK terhadap PKG. Dalam penelitian ini terungkap bahwa rendahnya kualitas pemahaman berhubungan langsung dengan rendahnya sikap guru BK terhadap PKG. Hubungan yang terjadi ini bersifat kausal, yaitu semakin rendah kualitas pemahaman guru BK terhadap PKG maka semakin rendah pula sikap yang dimiliki guru BK terhadap PKG, dan sebaliknya.Seperti yang telah diuraikan pada bagian terdahulu, rendahnya pemahaman dan sikap guru BK dalam menjalani PKG dapat berimbas kepada proses dan pencapaian hasil dalam menjalani PKG.

Kesiapan guru BK menjalani PKG merupakan suatu kondisi predisposisi dalam menghadapi pemberlakuan PKG. Sebagai prasyarat dalam pengukuran dan peningkatan kualitas kinerja, kematangan kesiapan, baik dalam aspek pemahaman dan sikap akan sangat menentukan kualitas tindakan, proses, dan hasil yang dicapai dalam menjalani PKG.

Pelaksanaan PKG adalah untuk perbaikan kondisi masa depan, khususnya perbaikan mutu guru BK dan kinerjanya. Terkait dengan kondisi sebagaimana telah dikemukakan dalam temuan penelitian ini, berkenaan dengan pemahaman dan sikap guru BK terhadap PKG, seluruh pihak-pihak yang terkait khususnya guru BK diharapkan memiliki pandangan ke depan tentang pelaksanaan PKG. Hal-hal yang berkaitan dengan arah ke depan terkait PKG, antara lain :

1. Sosialisasi panduan, sebelum menjalani proses PKG seluruh pihak yang terkait khususnya guru BK diharapkan memahami secara utuh dan menyeluruh terkait dengan konsep PKG sebagai salah satu rangkaian dari upaya profesionalisasi guru. Mengikuti pelaksanaan sosialisasi panduan PKG merupakan upaya untuk mengetahui dan memahami secara secara utuh dan menyeluruh terhadap konsep PKG

2. Pengarahan dari pimpinan, kepala sekolah sebagai pimpinan satuan pendidikan memiliki peran yang sangat penting dalam proses pelaksanaan PKG. Dalam menjalankan perannya ini, kepala sekolah diharapkan memberikan pengarahan demi suksesnya proses pelaksanaan PKG, pengarahan ini bermanfaat dalam persiapan dan menyusun program rencana kerja, pelaksanaan, serta tindak lanjutnya terkait PKG

3. Guru BK sebagai salah satu sosok yang akan dinilai kinerjanya harus memahami dan sekaligus berkewajiban menguasai materi-materi yang akan dinilai dalam PKG. Materi penilaian kinerja dalam melaksanakan proses pembimbingan bagi guru BK meliputi kegiatan merencanakan dan melaksanakan pembimbingan, mengevaluasi dan menilai hasil bimbingan, menganalisis hasil evaluasi pembimbingan, dan melaksanakan tindak lanjut hasil pembimbingan

4. Prosedur untuk suskes menjalani PKG, dalam mencapai proses dan hasil yang maksimal seluruh pihak yang terkait dengan PKG mesti memahami dan melaksanakan proses sesuai dengan prosedur yang ditetapkan. Terkait dengan kesiapan menjalani PKG ada beberapa upaya-upaya yang dapat dilakukan antara lain,: (1) memahami pedoman PKG, terutama tentang sistem PKG dan posisi PKG dalam kerangka pembinaan dan pengembangan profesi guru, (2) memahami pernyataan kompetensi guru BK yang telah dijabarkan dalam bentuk indikator kinerja, (3) memahami penggunaan instrumen PKG dan tata cara penilaian, (4) memberitahukan rencana pelaksanaan kepada semua pihak yang terkait, dan (5) melaksanakan proses penilaian sesuai rencana dan prosedur yang telah ditetapkan

5. Pengorganisasian, keseluruhan arah ke depan terkait dengan kesiapan dalam menjalani PKG tidak akan berjalan dengan maksimal dan mungkin akan berjalan tanpa arah apabila tidak diorganisasikan secara sistematis dan komprehensif. Pengorganisasian dalam rangka kesiapan menjalani PKG ini terkait dengan tugas pokok dan fungsi pihak-pihak terkait di sekolah secara umum meliputi : (1) merencanakan, menyusun, dan menetapkan rencana kegiatan ter-kait dengan kesiapan guru BK menjalani PKG, (2) melaksanakan kegiatan yang telah direncanakan dan ditetapkan, (3) mengevaluasi sejauh mana kemajuan yang didapat atas kegiatan yang telah dilaksanakan.

Dengan upaya dan arah ke depan di atas, diharapkan guru BK memiliki pemahaman dan sikap yang baik terhadap PKG. Sehingga muaranya tercipta suatu kondisi yang siap dalam menyongsong PKG sebagai upaya profesionalisasi guru. 
Temuan penelitian yang telah dibahas di atas tentu saja akan sangat bermanfaat dan berguna sebagai bahan evaluasi atas kinerja guru BK selama ini serta kaitannya dengan kesiapan menjalani PKG. Tidak hanya bagi wilayah atau lokasi yang diteliti oleh peneliti, tetapi juga bagi wilayah atau daerah lain. PKG yang akan dilaksanakan secara serentak di seluruh Indonesia juga menampakan berbagai gejala yang sama di berbagai daerah, seperti yang telah dikemukakan pada latar belakang masalah penelitian ini.

Berbagai gejala yang dimaksud antara lain adalah minimnya akses informasi dan sosialisasi tentang PKG dan belum terpenuhinya kualifikasi pendidikan yang menjadi prasayarat PKG. Kondisi-kondisi tersebut diasumsikan oleh penulis juga akan memberikan pengaruh terhadap rendahnya kualitas kesiapan guru BK menjalani PKG.

\section{SIMPULAN DAN SARAN}

Berdasarkan temuan dan pembahasan hasil penelitian maka dapat dikemukakan simpulan sebagai berikut.

Secara umum kualitas pemahaman guru BK dalam menjalani PKG di SMAN dan SMKN se-Kabupaten Batu Bara berada pada kriteria kualitas kurang baik. Berdasarkan variabel jenis kelamin, unit tugas, dan masa kerja tidak terdapat perbedaan, sedangkan berdasarkan kualifikasi pendidikan terdapat perbedaan yang signifikan, dimana nilai rata-rata guru BK dengan kualifikasi S-1 BK lebih tinggi dibandingkan S-1 Non-BK dan D-III BK. Secara umum sikap guru BK dalam menjalani PKG di SMAN dan SMKN se-Kabupaten Batu Bara berada pada kriteria kualitas kurang baik, dan tidak terdapat perbedaan sikap berdasarkan variabel jenis kelamin, unit tugas, kualifikasi pendidikan, dan masa kerja. Terdapat hubungan yang signifikan antara kualitas pemahaman dan sikap guru BK terhadap PKG di SMAN dan SMKN se-Kabupaten Batu Bara. Hal ini berarti, semakin baik kualitas pemahaman guru BK maka semakin baik pula sikap mereka terhadap PKG, dan sebaliknya.

Berdasarkan hasil penelitian, pembahasan, dan kesimpulan serta implikasi yang telah dikemukakan, ada beberapa saran yang diajukan sebagai tindak lanjut penelitian ini. yaitu sebagai berikut :

Bagi guru BK agar meningkatkan kualitas kompetensi dan kinerjanya melalui berbagai upaya seperti mengikuti musayawarah guru dan guru BK, seminar dan pelatihan, serta berkeinginan kuat dan mengupayakan diri untuk mengikuti studi lanjutan. Bagi Kepala Sekolah, agar mengupayakan peningkatan kualitas kesiapan guru BK dalam menghadapi PKG sekaligus peningkatan kualitas kompetensi melalui berbagai usaha seperti memfasilitasi musyawarah guru dan guru BK, mendorong dan memotivasi guru dan guru BK untuk mengikuti studi lanjutan. Bagi Dinas Pendidikan, untuk segera merumuskan dan mengambil kebijakan dalam mempersiapkan guru BK dalam menghadapi PKG dengan berbagai program seperti sosialisasi panduan, pelatihan, workshop, seminar, dan sebagainya. Dalam hal pengangkatan secara resmi guru BK sebagai pengampu pelayanan BK pada satuan pendidikan, harus berdasarkan ketentuan dan bidang keahlian serta kualifikasi pendidikan yang linear dengan bidang dan setting tugas masing-masing tenaga pendidik, dalam hal ini untuk guru BK minimal adalah Sarjana (S1) BK. Peneliti lainnya, hasil penelitian ini dapat dikembangkan melalui penelitian lanjutan berkenaan pengembangan dan peningkatan kualitas kinerja guru BK, seperti mengungkapkan kesiapan berdasarkan aspek keterampilan dan sebagainya.

\section{DAFTAR RUJUKAN}

Abdul Murad. (2005). "Standar Kualitas Kompetensi Konselor Profesional: Studi Pengembangan Standar Kompetensi di Lingkungan Pakar Konseling Perguruan Tinggi Negeri dan Konselor SMA Negeri". Disertasi diakses dari: http://repository.upi.edu/

Abu Ahmadi. (1999). Psikologi Sosial. Jakarta: Rineka Cipta.

A. Muri Yusuf. (1996). Teknik Analisis Data. Padang : Fakultas Ilmu Pendidikan Universitas Negeri Padang. . (2005a). Dasar-dasar Evaluasi Pendidikan. Padang: UNP Press. . (2005b). Metodologi Penelitian. Padang: UNP Press

.(2013). Metode Peneliatan Kuantitatif, Kualitatif dan Gabungan. Padang : Universitas Negeri Padang. 
Andi Mapiarre. A.T. (2006). Kamus Konseling dan Psikoterapi. Jakarta: Raja Grafindo Persada.

Balitbang, Depdiknas. (2010). Publikasi Pene-litian: Kelayakan Guru Mengajar. Diakses dari: http://pusatbahasa.kemdiknas.go.id/kbbi/

Danang Sunyoto. (2009). Analisis Regresi dan Uji Hipotesis. Yogyakarta : MedPress.

Dirjen PMPTK. (2010). Buku 2: Pedoman Penelitian Kinerja Guru. Jakarta: Kemendiknas.

Educational, Scientific, and Cultural Organization. (2008). Education develop-ment index. Paris: United Nations. Diakses dari: http://www.unesco. org/new/en/education/

F.C Gomes. (2003). Manajemen Sumber Daya Manusia. Yogyakarta: Penerbit Andi.

Hasan Alwi, dkk. (2002). Kamus Besar Bahasa Indonesia. Jakarta: Balai Pustaka.

Herman Nirwana. (1998). "Persepsi Klien tentang Konseling, Keterampilan Komunikasi Konselor dalam Konseling, dan Hubungan Keduanya dengan Pengungkapan Diri Klien”. Tesis tidak diterbitkan. Institut Keguruan dan Ilmu Pendidikan Malang : Program Studi Bimbingan dan Konseling.

Ilfiandra, Saripah, I., dan Agustin, M. (2006). "Peningkatan Mutu Tata Kelola Layanan Bimbingan dan Konseling pada Sekolah Menengah Atas di Provinsi Jawa Barat”. (Publikasi Penelitian), diakses dari: http://repository.upi.edu/

James L. Gibson. (2000). Organisasi, Perilaku, Struktur dan Proses. Edisi ke-5. Cetakan ke-3. Jakarta: Penerbit Erlangga.

Klaus M. Schwab. (2012). The Global Competitiveness Report 2011-2012. Jenewa: World Economic Forum. Dikases dari : http://www.weforum.org/

Nurnaninigsih. (2011). "Program Pelatihan Peningkatan Kualitas Pribadi Konselor SMA di Jakarta: Studi Deskriptif ke Arah Pengembangan Program Pelatihan Peningkatan Kualitas Pribadi Konselor SMA". Tesis. Diakses dari: http://repository.upi.edu/.

Peraturan Menteri Negara Pendayagunaan Aparatur Negara dan Reformasi Birokrasi Nomor 16 Tahun 2009 tentang Jabatan Fungsional Guru dan Angka Kreditnya, 2009. Jakarta: Kementerian Negara Pendayagunaan Aparatur Negara dan Reformasi Birokrasi.

Peraturan Menteri Pendidikan Nasional Republik Indonesia Nomor 27 Tahun 2008 tentang Standar Kualifikasi Akademik dan Kompetensi Konselor, 2008. Jakarta: Depdiknas.

Peraturan Pemerintah Nomor 19 Tahun 2005 tentang Standar Nasional Pendidikan. 2005. Jakarta: Depdiknas.

Peraturan Pemerintah Nomor 74 Tahun 2008 tentang Guru. 2008. Jakarta: Depdiknas.

Peter Salim. (1993). Webters New World Dictionary for Indonesia Users English Indonesian. Jakarta: Modern English Press.

Prayitno. (2009). Wawasan Profesional Konseling. Universitas Negeri Padang.

. (2010). Dasar Teori dan Praksis Pendidikan. Jakarta: Grasindo.

. (2011). Upaya Menyiapkan Siswa Menghapi Ujian Nasional. Makalah disajikan pada Seminar Nasional Bimbingan dan Konseling dengan tema "Peran Guru, Konselor, Kepala Sekolah, Orang Tua, Masyarakat, dan Pemerintah dalam Membantu Siswa menghadapi Ujian Nasional yang Bebas, Jujur, dna Akuntabel”. FIP : Universitas Negeri Semarang.

Pusat Bahasa. (2003). Kamus Besar Bahasa IndonesiaEdisi Ketiga. Jakarta: Depdiknas.

Ruky. S.A. (2010). Sistem Manajemen Kinerja: Performance Management System, Panduan Praktis untuk Merancang dan Meraih Kinerja Prima. Jakarta: PT Gramedia Pustaka Utama

Saefuddin Azwar. (2004). Metode Penelitian. Yogyakarta: Pustaka Pelajar 
(2005). Penyusunan Skala Psikologi. Yogyakarta: Pustaka Pelajar, Offset cetakan ke V.

Sears, Freedman, J.L \& Peplau. L.A. (1994). Psychology Sosial. Jilid 2. Alih Bahasa: Michael Adriyanto. Jakarta: Erlangga.

Sedarmayanti. (2009). Sumber Daya Manusia. Jakarta: Bumi Aksara.

Slameto. (1995). Belajar dan Faktor-Faktor yang Mempengaruhinya. Jakarta: Rineka Cipta.

Sugeng Hariyadi dkk. (2000). Laporan Penelitian tentang "Persepsi Siswa SMA Terhadap Tingkat Keefektifan Konselor dalam Memberikan Layanan Konseling Individual (Penelitian di SMA Negeri se-Kodya Semarang): Semarang : IKIP Semarang Press. Diakses dari : http://digilib.unnes.ac.id

Sugiyono. (2010a). Statistika untuk Penelitian. Bandung: Alfabeta. . (2010b). Metode penelitian Kuantitatif Kualitatif dan R\&D. Bandung : Alfabeta.

Suharsimi Arikunto. (2002). Dasar-Dasar Evaluasi Pendidikan. Jakarta: Bumi Aksara. . (2006). Prosedur Penelitian (Suatu Pendekatan dan Praktik). Jakarta: Rineka Cipta.

Undang-Undang Nomor 20 Tahun 2003 tentang Sistem Pendidikan Nasional. 2003. Jakarta: Kementerian Pendidikan Nasional.

United Nation Development Programe. (2007). Human Development Index. New York: United Nations. Diakses dari: http://www/undp. org/content/undp/en/ home.html

W.S Wingkel. (1996). Psikologi Pendidikan dan Evaluasi Belajar. Yogyakarta: Gramedia. 